\title{
REGULATION, CROSS-BORDER TRADE AND PRACTICAL NORMS IN WEST NILE, NORTH-WESTERN UGANDA
}

\author{
Kristof Titeca and Tom de Herdt
}

In February 2008, one of the authors visited an official of the Ugandan Ministry of Energy and Mineral Development in Kampala in order to get some additional clarification on the different legal regulations with regard to cross-border trade between north-western Uganda and two of its neighbours, the Democratic Republic of Congo (DRC) ${ }^{1}$ and Sudan. The official responded to the inquiry with an elaborate introduction to the legal background of these rules. However, he suddenly cut that explanation short and began to provide a very different one: how all these regulations do not matter much, as they do not mean a lot in the daily lives of the cross-border traders. He offered this summary: 'People along the border have established their own regime of trade. They regulate themselves by establishing rules and regulations which are different from the ones the government tries to apply., ${ }^{2}$ The state official's comment vividly recalls Das and Poole's comments on the 'margins of the state', when they argue that these are 'sites of practice on which law and other state practices are colonized by other forms of regulation that emanate from the pressing needs of populations to secure political and economic survival' (Das and Poole 2004: 8).

This article aims to analyse the regulations which govern crossborder trade in north-western Uganda. In doing so, it will demonstrate that this trade is neither chaotic nor unstructured. Olivier de Sardan's (2009) exploratory concept of 'practical norms' is particularly useful in exploring these 'non-policy mechanisms' (Ribot 1998: 344): it allows one to make sense of the divergence between official laws and regulations and actually enforced practices. In turn, actual practices of government officials are also profoundly influenced by social norms and perceptions of the state held by illegal traders and transporters. These practical norms are the result, then, of a bricolage (Cleaver 2002) of official and social norms, and are mediated through the power wielded by the cross-border traders, who effectively dictate terms to government officials. As will be shown, these practices do not necessarily challenge the image of the state (Migdal 1994; Migdal and Schlichte 2005),

\footnotetext{
KRISTOF TITECA is a postdoctoral fellow of the Research Foundation - Flanders (FWO), based at the Institute of Development Policy and Management, University of Antwerp.

TOM DE HERDT is a lecturer at the Institute of Development Policy and Management, University of Antwerp.

${ }^{1}$ In this article, the Democratic Republic of Congo will be referred to as 'the DRC' or 'Congo'.

${ }^{2}$ Interview, official in the Ministry of Energy and Mineral Development, Kampala, 27 February 2008.
} 
but rather have to be seen as practical solutions to local enforcement problems.

Research was conducted by the first author (Titeca) during different phases of field research in 2008 (January-February and September-October), 2009 (January-February) and 2010 (January-February), but also drew on data gathered during earlier periods of field research between 2005 and 2007. Interviews were conducted not only with active traders, but also with the relevant government actors (such as customs officials, security agencies and others) and with the general population (consumers). Research was mainly conducted in north-western Uganda and the border town of Arua (which is a central point in this trade), but the traders were also accompanied to north-eastern Congo and the border with southern Sudan. Interviews often dealt with sensitive issues such as bribes or the smuggling of illegal goods. While doing research on cross-border trade in Arua for some years (since 2005), the first author had managed to establish relationships of trust with key actors in this trade, which gave him access to crucial information and allowed him to tackle these sensitive issues. He worked with two research assistants with whom he has collaborated for several years while studying the informal economy of Arua. They were (and are) still active in the informal economy and cross-border trade. In this research context, traders were very open about their activities and were eager to introduce colleagues who could provide more information. Government officials were also very open about their practices; again, trust had been established over several years. All these factors helped in gaining access to the data we present here.

\section{GOVERNANCE OF THE CROSS-BORDER TRADE IN ACTUAL PRACTICE}

The major dynamics of the regional trade between north-western Uganda, north-eastern Congo and southern Sudan can be summarized as follows: manufactured goods are traded-following more or less standard legal procedures - to Uganda, the DRC or Sudan from Kenya (Mombasa/Nairobi), where they in turn have been imported from foreign places such as Dubai and the Far East. Part of these goods, having reached the DRC or Sudan, are smuggled back into Uganda where they make higher profits than normally taxed goods The town of Arua in north-western Uganda plays a particularly central role in these trading dynamics: from this town, smuggled goods are dispatched in different directions. A good example is sugar: daily, an estimated $40,000 \mathrm{~kg}$ of sugar is smuggled into Arua on bicycles by transporters who ferry the sugar in $50 \mathrm{~kg}$ bags. From Arua, sugar is distributed all over West Nile and northern Uganda: of the total, it is estimated that only about a quarter is for local consumption, while the remaining sugar is traded in the wider region. Other goods from Kenya stay in the DRC or Sudan, where they remain to be sold. Foodstuffs and natural resources originate from the DRC, from where they are exported to Uganda, which in turn exports them to other countries. For example, 


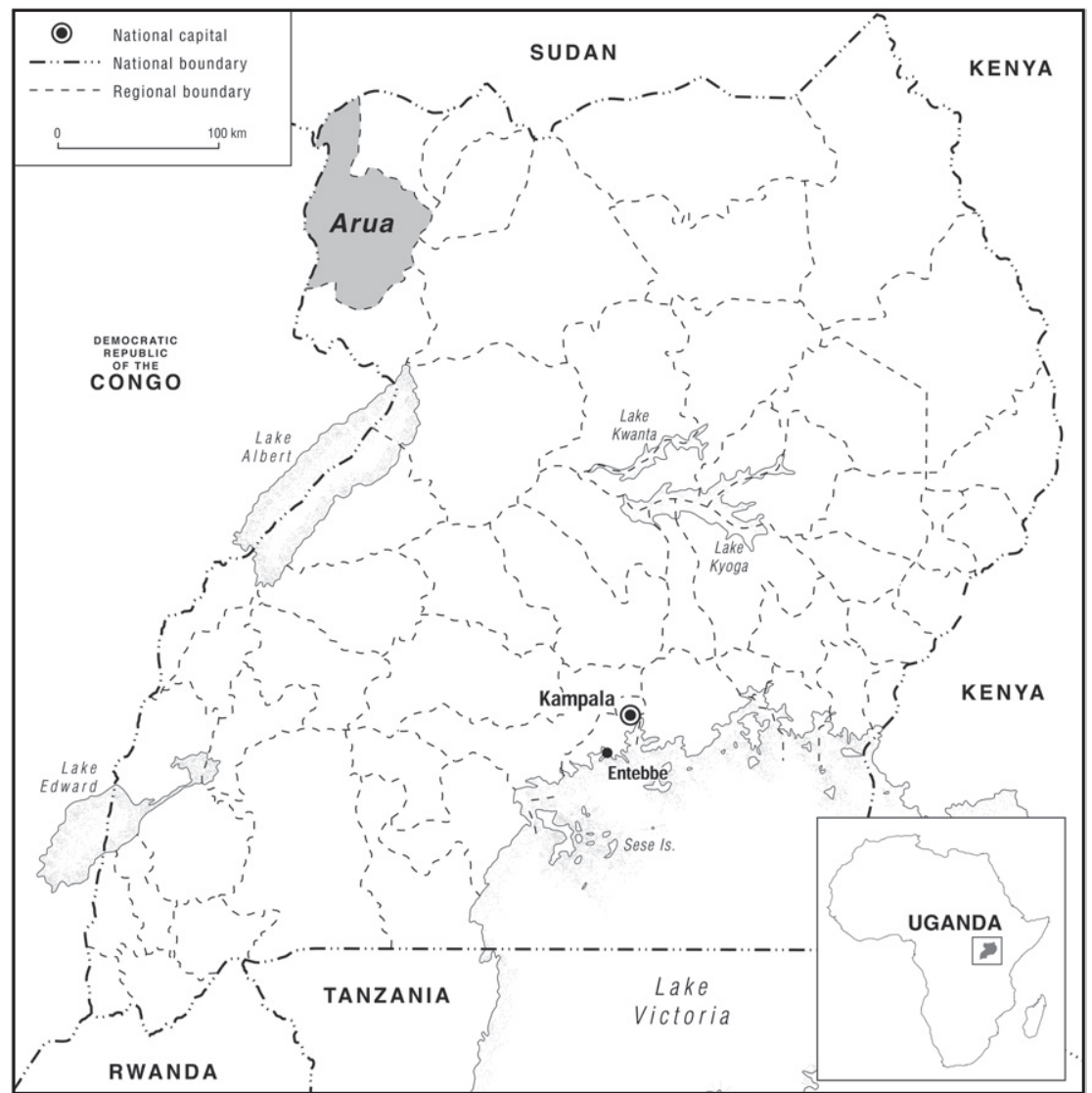

FIGURE 1 Map of Uganda, showing the border regions

there is a major trade in timber, which is bought in the DRC, smuggled into Uganda, and then smuggled again to Sudan.

Whereas the DRC and its border markets mainly have an entrepôt function for Ugandan traders, the trade with Sudan is primarily direct. The 2005 Comprehensive Peace Agreement (CPA) in Sudan has created a major demand for goods in what had remained virtually a virgin market for more than two decades (1983-2005). This regional trade is nothing new: Meagher (1990) describes it as a continuation of historical trading patterns which culminated in intensive regional trade in the $1980 \mathrm{~s}^{3}{ }^{3}$ Traders from north-western Uganda are particularly active: they take goods to Sudan and Congo, and smuggle goods from these countries back into Uganda.

Most of this cross-border trade tries, in varying degrees, to avoid state control: legal opacity and high taxes do not stimulate traders to

\footnotetext{
${ }^{3}$ An overview of the evolution of this trade since the 1980s is given in Titeca (2009b).
} 
conduct their trade through state channels. Moreover, apart from the high taxes, the different government agencies are known to charge the traders informal 'fees' - bribes - at the border points. For example, it is estimated that about thirty state services work on the borders in the north-eastern Congolese province of Ituri, although officially only four of these agencies are allowed to do so (Tegera and Johnson 2007). ${ }^{4}$ Trade is therefore hindered by a whole range of fees and taxes. For example, a (UK) Department for International Development (DfID) report (2007: 20-3) on the trade in natural resources shows how 23 different fees and taxes have to be paid when minerals are traded between Walikale and Goma. This is not a new phenomenon, either, but something which has been happening for some considerable time. Janet MacGaffey (1991: 21) wrote on cross-border trade in the late 1980 s that ' $\mathrm{Up}$ to 70 administrative steps may be involved in moving commodities legally across African borders; in Zaïre, for example, exports require 39 steps and imports 30.'

All these state agencies are there for a reason: border points are seen as particularly profitable, and an important part of the border revenue escapes state control. This leads to a situation characterized by uncertainty and ambiguity over legal rules; as Schomerus (2008: 6) succinctly comments, 'trade is stymied by lack of transparent and fair border procedures and affordable fees'. As a consequence, much of the cross-border trade in the region to a greater or lesser extent takes place outside or on the margins of the law: official border crossings are seen as particularly expensive because of the high level of taxation, the opacity, and the presence of so many state agencies (cf. Tegera and Johnson 2007). Even the cross-border trade which takes place through border points often avoids legal regulations. For example, the Bank of Uganda has a large research project in which the amount of unregistered (smuggled) goods through official border points is estimated: in 2006, the total of such informal trade between Uganda and Sudan was estimated at US\$9.1 million. In 2007, increased trading opportunities created by the peace agreement in southern Sudan and improved security also led to an increased unregistered trade, totalling US $\$ 456.4$ million for that year. The total informal trade between Uganda and the DRC was estimated at US\$91.7 million in 2006 and US $\$ 174.8$ million in 2007 (UBOS 2007, 2008). The Uganda-DRC border in north-western Uganda is traversed by an estimated 300 smuggling routes around the six official border points. The above figures only show the amount of unregistered goods through official

\footnotetext{
${ }^{4}$ The Presidential Decree of 28 March 2002 only authorizes these four institutions: L'Office de Douanes et Assises (OFIDA), La Direction Générale de Migration (DGM), L'Office Congolais de Contrôle (OCC) and Le Service de l'Hygiène aux Frontières. See Radio Okapi, 'Ituri: environ 30 services de l'état opèrent aux frontières', 〈www.radiookapi.net〉, accessed 5 April 2009. An overview of the Congolese state agencies which are de facto present on the eastern Congolese borders is provided in the excellent report by Tegera and Johnson (2007) on cross-border trade from eastern DRC.
} 
border points, which means that the value of the 'real' cross-border trade is much higher.

An increasing proportion of economic activities thus bypasses statebased regulations and is theoretically illegal. As cross-border trade to a large extent takes place outside of the state framework, it could be considered as part of the 'informal economy'. Yet the pervasive character of the informal economy reflects recent discussion of the term: the concept has been criticized as obsolete, since in the absence of a functional formal economic sector, the informal sector has also ceased to exist. As Klein explains (1999: 568): 'As a paired negotiation each marker depends on the integrity of the opposing term. But with criminalization, the key referent of formality has defected across the binary divide, and become absorbed by informality. The rest is simple: no formal sector, no informal sector.' As the founding father of the 'informal economy' concept, Keith Hart, concludes, 'state collapse has attained such proportions that it seems almost pointless to clarify that the informal economy is the dominant sector' (Hart 1995: 122; our translation, emphasis in original; cf. Hart 2001).

Yet this does not mean that the trade we are considering is unregulated. Instead of looking at what is absent, argues Meagher, we should be looking not at the 'absence' of formal regulation, but at 'alternative forms of regulation operating below and beyond the framework of the state' (Meagher 2008: 4). More generally, there is a wide literature on what de Soto (2000) calls 'extralegal' regulatory mechanisms: it covers street vendors (Bromley 1978; Cross 1998), the drugs trade (Reuter 1985; Hagedorn 1994), gang life (Venkatesh and Levitt 2000; Rodgers 2006) or mafia structures (Gambetta 1993; Varese 2001). Specifically for the informal economy in sub-Saharan Africa, Janet MacGaffey (1991: 152) has already argued that the 'real economy of Zaire is not haphazard but institutionalized, operating according to a system of rules known to all participants'.

Others prefer to start the other way around, by analysing how states and their administrations 'really' govern in particular domains and settings. This literature denies the existence of a neat boundary between the 'formal' and the 'informal': the sectors are articulated with each other; the 'real' economy forms an integrated whole. These authors also deny that the informal economy would be a better-functioning substitute for the formal economy. Instead, emphasis is put on the functional relationships they entertain with each other. For example, according to Béatrice Hibou, the 'real' economy in sub-Saharan Africa becomes an 'economy of dirty tricks' in which the 'manipulators of violence and deception are also the main mediators of economic activity' behind the façade of their official activities (Hibou 1999: 112-13). In her work, Janet Roitman (2004) explains how a militarycommercial nexus is central in this regulatory authority, while William Reno $(1998 ; 2000)$ analyses how informal economies are part of the general criminal strategies of rulers in shadow states (cf. Chabal and Daloz 1999). In certain accounts emphasis is placed on how African states' increasing tendency to reproduce themselves by engaging in 
the criminal economy can draw on specific cultural trajectories, which Bayart (1999) calls the 'social capital of the felonious state'-a claim made rather to highlight the way in which such a course of action gains purchase in sub-Saharan African countries than to single out a specific trait of these countries, as he demonstrates later on by pointing to similar practices in European contexts (Bayart 2004).

Although the above view has its merit in highlighting the functional relationship between the formal and informal sectors, particular attention is given to the criminalization of the informal economy: through this single concept, the overall functioning of the informal economy (or African socio-political realities in general) is explained. However, these broad concepts do not help to explain the microregulation of these economies. They do not help one to study the dayto-day 'real' governance of the informal economy, which is composed of 'multiple dimensions, some convergent and others contradictory; it is also the product of local, sectoral and individual micro-dynamics' (Olivier de Sardan 2009). These micro-dynamics have not been well understood, nor have they been the subject of much in-depth empirical analysis. A useful concept in analysing the micro-dynamics of this articulation is what Olivier de Sardan calls 'practical norms'. As he argues, within the large literature on African states, a general consensus emerges that there is conspicuous divergence between the official norms of these institutions, which are largely patterned on Western models, and the actual behaviour of the state employees (ibid.: 4). These practices are not chaotic or anomalous; rather, they are regulated, organized and structured, yet unofficial. The 'practical norms' concept is particularly useful because it shows how legally under-regulated settings are not characterized by a lack of regulation. On the contrary, Olivier de Sardan argues, 'One might even go so far as to say that the regulation of extra-official practices has produced an excess, rather than a lack, of norms. It remains to discover what these non-official norms are!' (ibid.: 9). Some are very visible, as they are part of explicit agreements between different actors; while others are part of local routines and not necessarily consciously expressed. Because they are implicit, it is therefore 'the responsibility of the researcher to isolate, identify and analyse them, starting from the practices of the actors as well as their discourse' (ibid.: 14). This is exactly what our article aims to do with regard to the cross-border trade in north-western Uganda: we describe the practical norms used by various categories of actors in the regional cross-border trade. We shall show that this trade is governed by a range of practical norms structuring the behaviour of both traders and government officials. It is an impossible task to give an overview of all the norms in play in the micro-dynamics of cross-border trade, but we want to analyse a number of important ones.

The importance of practical norms does not signify that official norms - state regulations - become completely irrelevant; rather, they are operationalized in a different way than intended. In the field of cross-border trade, Chalfin argues (2001: 203), trading practices rely 
'on particular understandings and activations of state regulations': customs officials can decide to punish a smuggler or they can help him to under-declare, undervalue, and so on. The work of Blundo (2006) on the functioning of public administrations in sub-Saharan Africa demonstrates how state rules are constantly negotiated, which results in particular compromises over the rules of the game.

It is also useful to differentiate between practical norms and social norms. The latter define what is considered legitimate in particular contexts. Social norms are not necessarily made explicit, but are shared by an entire society or emanate from it (Olivier de Sardan 2009: 8). They play an import role in the development of what is considered 'licit' and 'illicit' (Abraham and van Schendel 2005: 19). The influence of social norms highlights how the practices we are considering should not be defined only negatively - as deviations from official state practices - but also, more positively, as moral codes in their own right. For example, smuggling could be considered in the light of a morality that favours kinship ties linking adjacent territories over state-imposed borders that separate them (Migdal and Schlichte 2005: 25). It is important, however, to distinguish conceptually between social norms and practical norms, 'which bear no relation to either "tradition", or culture in general, common values, or a shared "network of meanings" but are nonetheless effective' (Olivier de Sardan 2009: 13)-effective, that is, in aligning people's expectations about others' behaviour.

The fact that certain practices are considered illegitimate-through the social norms present in society-does not mean that they actually fail to guide the behaviour of state employees or non-state actors. The power balance in which state and non-state actors are involved plays an important role. Both state and non-state actors may try to include social or legal norms in routinized patterns that become institutionalized in a more stable form or 'practical norm', but, in the end, what counts is the effectiveness of the norm in aligning others' expectations and, thereby, its value in smoothing the process of interaction. The prevalence of practical norms is therefore rather a function of the inventory of tactics and manoeuvres available to all parties involved, than a reflection of either 'legal' or particular 'social' norms. Practical norms are essentially the product of collective bricolage (Cleaver 2002).

The configuration of power relationships linking different actors determines the extent to which these practical norms deviate from the official or social norms. For example, if the central state has a rather powerful position, the 'practical norms' of the government officials in border areas will probably not be very different from official norms. Inversely, if non-state actors wield considerable power, they will manage to bend practical norms away from official state practices. The existence of social norms alone is therefore not enough. This is not a static but a dynamic process. The concrete manifestation of practical norms will depend on the specific configuration of power that sustains the modus vivendi of different social actors in a specific domain (Olivier de Sardan 2009). 
Practical norms, many of which are in theory illegal, do not automatically 'undermine the recursive patterns of rule at the heart of national political order and integration' (Chalfin 2001: 203). On the contrary, they are essential to the functioning of state institutions, and highlight how public authority - or stateness - 'can wax and wane' because 'state institutions are never definitively formed, but... a constant process of formation takes place (Olivier de Sardan 2005: 16; Steinmetz 1999: 9)' (Lund 2006: 686). This is similar to what Migdal (1994) and Migdal and Schlichte (2005) call the difference between the state image and state practices: in their daily practices, state officials often do not conform to the image of the state; instead, they engage in a variety of practices that partly reproduce, but partly also deviate from the image of the state as a coherent, unified and supreme rule maker in a given territory. State practices are defined as 'diverse, multiple actions of state actors as well as the myriad responses and interactions with state officials or nonstate actors' (Migdal and Schlichte 2005: 14-15). The basic issue is that state representatives find themselves in 'an already established network of powers and representations' (de Certeau 1984: 18). The bricolage of locally enforced practical norms can be seen as a pragmatic solution to this issue.

The practical norms concept is not uncontested. The main criticism is that it is mainly exploratory, with limited analytical power, as it does not explicitly ask why official rules are ignored, how or why practical norms are arrived at, and why officials and other actors adhere to them (Kelsall 2009: 5). In our view, however, the relative underspecification of the precise mechanisms at work in generating and sustaining these norms makes the concept particularly interesting as an invitation to engage in empirical analysis. How have these norms emerged in particular settings? How did they change over time? How are they enforced? And, to begin with, was there a basic issue of norm pluralism to be bridged by them? We shall indeed begin by showing how the practical norms we are studying bridge legality and the wider moral economy of cross-border trade in the region. Second, we shall show which practical concerns play a role in sustaining the norms, and how deviations from them activate open power struggles. And third, we shall show how concrete events played a role in their emergence.

\section{THE MORAL ECONOMY OF CROSS-BORDER TRADE IN NORTH-WESTERN UGANDA}

Even though much of the cross-border trade flows through illegal channels, it is seen as thoroughly legitimate by Ugandan traders, something which will be explained in this section. In the first place, as described in Meagher (1990), this cross-border trade has deep historical roots, and is enhanced by the fact that similar ethnic groups live on different sides of the border and are therefore in close contact with each other. Outside interference in these contacts-and also 
in trading contacts - is perceived as intrusive. Secondly, and most importantly, cross-border trade is to be understood within the national politics of Uganda. People in West Nile, and northern Uganda in general, feel marginalized by the regime of President Museveni, which has been in power since 1986. The region therefore strongly supports the opposition. During previous regimes (and particularly during that of Idi Amin, who originated from West Nile), West Nilers had access to key positions in the power structure. People feel this access is currently denied, leaving them marginalized on several levels: they complain of a lack of regional infrastructure and exclusion both from the civil service ${ }^{5}$ and influential government positions. ${ }^{6}$ The lack of infrastructure is compounded by the absence of the necessary development programmes. Several rebel groups emerged in the area after President Museveni came to power, among them the Uganda National Rescue Front II and the West Nile Bank Front. Although these groups only had limited support, they translated widely held grievances, which were related to these feelings of marginalization (Leopold 2005: 46). In this situation, cross-border trade is seen as an indigenous way to provide development denied by an incapable and/or unwilling national government. ${ }^{7}$ In other words, the cross-border trade can be seen as a regionalization of the famous 'Système D' in Mobutu's Zaïre which allowed the border population to 'fend for itself'. One trader summarized these feelings in an interview:

This government is not taking care of us. We have no industries, no jobs, nothing.... The only thing we have is the border. It allows us to earn a living with the little we have. We buy something in Congo and we sell it here; or we take something to Sudan. ${ }^{8}$

Because so many people are convinced that the government is not going to deliver the goods necessary to enhance their lives, the expanding cross-border trade is seen as a 'source of economic freedom and empowerment' (Roitman 2004: 32). It could be argued that the area has chosen to turn away from the national state, or at least from its regulatory framework: illegal cross-border trade has been embraced as a legitimate option, which conflicts with the bureaucratic rationality of the different state institutions. A similar situation is described by Odegaard in Peru, when she observes that 'In the discourse of the traders, the state is in many ways de-moralized while the market is moralized' (2008: 261). It can be said that there is a 'moral economy'

${ }^{5}$ This is felt all over northern Uganda and is confirmed by press reports: see, for example, Nalugo 2008

${ }^{6}$ They are disgruntled, for example, because people from West Nile only have access to positions such as Minister of State, and do not control actual ministries or the resources these command. For an investigation of the access of the different regions to public funds, see Mwenda 2008.

${ }^{7}$ The domination of the regional trade by Ugandans is a point which is developed in detail elsewhere: see Titeca 2009 b.

${ }^{8}$ Interview, trader, Arua, 7 August 2009. 
in play which regards cross-border trade-and also, or particularly, trade which takes place outside of the legal framework - as legitimate, while attempts by the government to regulate this trade are seen as illegitimate. Simply, the idea of what constitutes legitimate practice does not correspond with the legal system. ${ }^{9}$

In the (very different) context of a peasant subsistence economy, Scott some time ago defined the moral economy of the peasants as a 'notion of economic justice and their working definition of exploitation - their view of which claims on their product were tolerable and which intolerable' (1976: 3). His observation can also be applied to the cross-border trade, although this moral economy is not one of a 'subsistence ethic', but rather an ethic in which cross-border trade is seen as a particularly legitimate source of survival-or, as will become clear in the next sections, in the discourse of the traders, their 'food'. In this situation (largely illegal) cross-border trade is not only considered to be a legitimate option for individuals, but for the whole region.

Moreover, it has a clear political meaning. This reflects earlier findings in the seminal work of Janet MacGaffey (1987; 1991), who considers unrecorded trade not only as an economic phenomenon, but also as political option. Describing the emergence of an indigenous bourgeoisie of local entrepreneurs without political position during the 1980s, MacGaffey (1987) demonstrated how unrecorded trade was a political option defying the power held by a parasitic class. 'In the second economy, people are taking matters into their own hands and organizing an unofficial system; they are compensating for the inability of the state to supply the infrastructure, services, and protection of individual rights the citizens of any nation need and expect' (MacGaffey 1991: 39). And turning their attention to traders who move goods between Congo and Paris in the late 1990s, she and co-author Bazenguissa-Ganga reach a similar conclusion, by arguing that their activities represent protest and struggle against exclusion through this transnational trade (MacGaffey and Bazenguissa-Ganga 2000).

Similar feelings are felt in West Nile, where cross-border trade is perceived as a 'home-grown' or 'indigenous' form of development which allows people in the border areas to 'fend for themselves' in the light of a neglectful national government. It is therefore important to stress, as we do again, that strong feelings of legitimacy support the cross-border trade: although most of this trade happens illegally, it is seen as a licit option. Conversely, the actions of the government are considered decidedly illegitimate. ${ }^{10}$ These social norms alter the parameters in which state agents are able to work and make it very difficult for officials to implement official regulations. For example, customs officers complain about continuous harassment and threats to

\footnotetext{
${ }^{9}$ Titeca (2009a) demonstrates how certain organizations (vigilantes) are also able to 'fill the gap' by providing protection of property rights to smuggled goods.

${ }^{10}$ Abraham and van Schendel (2005) make a similar distinction between 'legality' and 'licitness'.
} 
their security. One Uganda Revenue Authority (URA) official offered the following summary:

By working for the URA, I put myself at risk! Sometimes I cannot go and drink in public, someone could come and hit me with a bottle! Someone could recognize me from a confiscation and want to take revenge!... The community, they help the smugglers. When they are being followed by us, they can make us lose direction. ${ }^{11}$

Nugent and Asiwaju (1996) would understand this reaction. They argue that border officials are in a vulnerable position vis-à-vis the local population under conditions in which 'it may be virtually impossible to remain faithful to regulations.... The official ceases to look much like a representative of the state and instead bears the appearance of someone who has been taken into the embrace of the community concerned' (Nugent and Asiwaju 1996: 7-8). Another Ugandan customs official corroborates such a finding in the following way:

The only possible way in which we can do our work here is to come to a mutual understanding with the population and the traders.... You can come here and try to implement the rules from Kampala, but it will not work: you will put yourself at risk, and the community will disorganize you and your customs point. We have to associate ourselves with the smugglers. If we would not be doing this, we would be seen too much as the enemy: we would not be able to move without security! ${ }^{12}$

In response, government officials have developed certain mechanisms to create this 'mutual understanding' with the local community. Some of these practical norms are quite straightforward: for example, smaller quantities of goods can be smuggled across the border, under a shared understanding that they will not be confiscated by the customs officials. These quantities are fairly specific. For example, traders indicate that they are allowed to bring in one carton (20 packets) of cigarettes; one or two jerry cans of fuel (20-40 litres); or 10-15 bags of charcoal. A more explicit arrangement governs the socalled 'threshold days' or 'tax-free moments' organized by the main two customs points in this area. About once a month, they offer a cut rate to the traders: smaller quantities of goods do not have to pay taxes; whereas larger quantities of goods receive major discounts. This is communicated on the day to a number of traders, who in turn inform their colleagues. According to local traders, customs points have to collect a certain amount of taxes each month. Once this 'threshold' is reached, there no longer is the same pressure to collect taxes; this is when 'threshold days' or 'tax-free moments' are organized. Most traders are convinced this is an official government practice. According to the local customs officials, however, it is an unofficial practice, which

\footnotetext{
${ }^{11}$ Interview, URA official, Arua, 27 January 2010.

${ }^{12}$ Interview, Uganda customs officials, West Nile, 7 February 2010.
} 
they only organize to improve relations with the local community-or, as one customs officials phrases it,

to show our appreciation to the local community.... It is an important way of building public relations in your area; this is done to generate trust among the population.... This is a strictly local arrangement, the national government does not know about this. ${ }^{13}$

Similarly, in the implementation of government regulations, officials need to identify certain priorities: not all rules can be enforced, so they must focus on certain key tasks. This does not mean that the regulations have lost all meaning, or that officials have lost all their powers: similarly, traders have to show their 'understanding' in what can be considered an ongoing negotiation process. In this process, certain priorities are established and then translated into 'practical norms'. For example, some goods and actions are clearly perceived to be 'more illegal' than others, both by the traders and the government officials involved. This normally is the case in relation, for example, to drugs and weapons, on the one hand, and smuggled food products on the other. ${ }^{14}$ Drugs and weapons are seen as much 'more illegal' in the sense they are less 'legitimate' to deal in. This is as one might expect; it is, however, surprising to find such distinctions made between fairly similar products. For example, illegal papyrus exports - in which major under-declaration is allowed or sometimes no taxes are paid-are considered less dangerous and 'illegal' than the export of timber. In this case the 'less illegal' export of papyrus is therefore used to cover up the 'more illegal' export of timber. In this context, the terms 'legal' and 'illegal' have become very blurred: for example, when people in north-western Uganda refer to 'legal' timber traders, they refer to timber traders who do not circumvent the customs points on the DRC-Uganda border. These 'legal' traders, however, can still bribe the customs officials, under-declare the timber or cover the timber with illegal (undeclared and/or untaxed) papyrus to bring it across the Uganda-Sudan border. Under-declaration and covering timber with 'less illegal' goods is not considered illicit by either the traders or the customs officials, who seem to have an implicit agreement on this. This reflects identified priorities in the (extra-legal) negotiation process between traders and government officials.

Why do the government officials do this? In other words, why have these practical norms emerged? As explained above, in the general

\footnotetext{
${ }^{13}$ Interview, Uganda customs officials, West Nile, 8 February 2010. This was confirmed by interviews with national government officials, who are not aware of this practice: they consider it illegal and denounce its existence (Interviews, URA officials, Kampala, 9/10 February 2010).

${ }^{14}$ Little offers an example of this: 'In 2001 some local Kenyan officials with whom I spoke did not think cattle were contraband commodities, nor the trade illegal, when in fact on paper it really is. Other smuggled imports, such as drugs or weapons, are secretively traded but treated as more illegal or dirty in status than animals. If discovered by Kenyan border officials, they likely will be confiscated' (2005: 19, emphasis in original).
} 
context of north-western Uganda, where communities see cross-border trade as decidedly legitimate, these practical norms are inspired by concerns of personal safety-implementing official rules creates major security risks for the personnel involved. This also has consequences for state institutions, as it becomes impossible for these to function in 'official', standardized, formal-bureaucratic ways: strictly implementing national laws and regulations would lead to constant clashes and 'disorganize trade and the overall region'. ${ }^{15}$ This is in turn related to the power position of the cross-border traders: they effectively have the power to 'disorganize' the government officials and therefore to influence the compromise between official and social norms. Several underlying factors explain this power: first, the traders are easily organized, and this is particularly the case for the fuel smugglers (the 'OPEC Boys'), who are divided into several sub-groups within an overall organization, and who are in close contact with the other traders and the wider population (Titeca 2006), something which will be illustrated below. Second, the area has a long history of rebel movements, and there is a strong fear that, if ousted from the crossborder trade, traders might be tempted to take up arms again. For example, particularly among the OPEC Boys, there was a correlation between smuggling, confiscation and rebellion: in the late 1990s and early 2000s, a number of OPEC Boys took up arms out of frustration at regular confiscation of their goods. They later returned to the cross-border trade (Titeca 2006). Finally, it was explained above how the moral economy of cross-border trade is strongly political in nature: the population feels it has to 'fend for itself' in the light of government neglect. Government confiscation is therefore perceived as an inherently political act: local traders perceive confiscation of their goods as another attempt by the national government to marginalize the area.

The Ugandan national state is well aware of this, and naturally adjusts its practices in this light: it has little to gain and much to lose by attempting to shut down this cross-border trade. Although it is detrimental to the national state economy, it is politically very important to the national state. For these marginal areas, extrastate cross-border trade is an important alternative socio-economic system of employment and trade (Pugh and Cooper 2004)-which, as Carolyn Nordstrom puts it, is fundamental and necessary for development in these marginal areas (2004: 113; 216-20). She argues that war-torn countries such as Angola cannot develop themselves without relying heavily on this non-state-based development. Uganda's national government is fully aware of the political significance of the trade: throughout the various periods of field research undertaken in the region, several customs officials claimed to receive explicit

${ }^{15}$ Interview, customs official, West Nile, 8 August 2009. 
instructions from their national offices in Kampala to remain 'low key' during election periods - in other words, to limit their confiscations. ${ }^{16}$ Although this signifies an increased loss in taxes-and is therefore bad for the state-its political importance prevails. This can be seen as unspoken encouragement by the Ugandan government of the border population to 'fend for themselves', as Mobutu more explicitly recommended in comparably difficult (Zaïrean) circumstances. ${ }^{17}$ In a similar way, Hecht and Simone argue that government actors on the Nigeria-Benin border turn a blind eye to smuggling practices that are crucial to the economies of both countries (1994: 20-1).

Certain key events play an important role in the creation, adaptation or simple maintenance and reinforcement of these practical norms: in this way such norms become incorporated in the local 'habitus' (Olivier de Sardan 2009: 14). Implicit arrangements between the different actors active in the field of cross-border trade become explicit through these events, which serve as reference points or 'open moments' (Lund 1998) in the creation, emphasis, or adaptation of a practical norm. Thus in the cross-border trade activities of Arua District, it is perceived as illegitimate to confiscate smuggled goods within town and/or to use excessive violence in chasing smugglers. The root of this practical norm can be traced back to a major event in 2001: during this period, the government was particularly strict on smugglers, confiscated all smuggled goods (even smaller quantities), and often used violence in doing so. This was the work of two paramilitary units in particular: the mobile police and the 'Special Revenue Protection Services', which at the time had a notorious reputation among the population. At some point, mobile police officers arrested two OPEC Boys who were selling their fuel within town. This event not only breached the practical norm in which smuggled fuel is not supposed to be confiscated within town (Titeca 2006). It also involved violent mistreatment of the arrested smugglers (they were allegedly tortured in an attempt to extract a bribe). The remaining OPEC Boys, together with other traders and the wider population, mobilized the townspeople in protest; the police officers were very nearly lynched and revenge was taken on all symbols of governmental power: local council offices, posters of President Museveni, and so on. In response, the government brought in the army and arrested several OPEC Boys. Severe fighting broke out in Arua Town, in which 15 people were severely injured. Immediately, national and local politicians looked for ways to resolve the escalating tension. With the security of the region at stake, they were able to broker intervention at the highest national level: when admitted to

\footnotetext{
${ }^{16}$ Interviews, customs officials, 2006-9. This was not only the case in northern Uganda, but also at border posts in western Uganda.

${ }^{17} \mathrm{I}$ have written elsewhere about the 'political' meaning of cross-border trade, in which it is prudent for governmental actors to tolerate smuggling activities. In Arua Town, the above-mentioned OPEC Boys are prime local symbols of this freedom to 'fend for yourselves'-partly, as we have seen, because they are ex-rebels who need to be kept 'on side' (Titeca 2006; and see also Titeca and Vervisch 2008: 2209-11).
} 
hospital, the injured traders were visited by the President, who was campaigning in the area; and were even given financial compensation by him for their injuries. ${ }^{18}$ This visit can be seen as a firefighting exercise that recognized the political and social power of the crossborder traders. Besides their political significance (as discussed above), the event also clearly illustrated the traders' ability to provoke chaos. This combination of factors gives them their leverage in negotiating the practical norms governing their trade. One of these is not using excessive violence against the traders, something for which the 2001 event is generally regarded as a reference point, one reiterated and reinforced by other subsequent events. In mid-2009, for example, the URA tried to confiscate a few jerry cans of fuel; in the process, one person died after being hit by their car. The OPEC Boys and other traders then attacked the offices of the URA and tried to set it ablaze. In a repeat incident shortly after this, in August 2009, the URA tried to confiscate smuggled cigarettes, and shot a trader in the arm. The OPEC Boys responded by leading a second attempt to fire the URA offices - which were then shifted to a better-secured compound outside of town. In short, URA officers had disregarded practical norms and paid the price - thus further reinforcing these norms.

Another practical norm is that women carrying babies will not be subject to strict border controls, which allows them to bring in untaxed goods. Again, this reflects the general perception that smuggling is a way to 'fend for oneself'; within this context, it allows women to feed their families. An event in 2007 is seen as a reference point, repeated by traders and government officials alike. Early in that year, the URA confiscated smuggled cigarettes and sugar from a woman carrying a baby on her back. In protest, the woman threw herself on the ground after depositing her baby in the car of the URA, refusing to take it with her. As a trader explained, 'By doing this, she wanted to show the officials that they were taking away her food, that she could not feed her baby any more. The baby had to go where her food was going, as she had lost all her capital!'19 The baby remained with the revenue authorities for two days, during which there were community protests as well as political pressure, until the baby and the confiscated goods were returned. Other examples were given by traders and government officials of similar cases which happened after this event, but this remains the prime reference point: after this, women carrying babies were not subject to strict border controls or punishment. Again, this has to be seen in the general political context of cross-border trade, in which women carrying babies have become archetypal symbols of persons fending for themselves - and in this way 'feeding' their families and the wider region. This is how policy mechanisms - in the local cross-border area, with reverberations higher up - are implemented and negotiated.

\footnotetext{
${ }^{18}$ Information independently given by several first-hand witnesses (various interviews, 2005-7).

${ }^{19}$ Interview, trader, Arua, 3 February 2010.
} 
Further, both for traders and government officials, these practical norms through which state rules and institutions are negotiated with society are key in countering the unpredictability of the crossborder trade and in smoothing transactions. They can therefore be considered what Moore (1978: 50) calls 'processes of regularization'. They produce rules and regulations in which 'people try to control their situations by struggling against indeterminacy, by trying to fix social reality, to harden it, to give it form and predictability'. ${ }^{20}$ In the 'unstable' and potentially dangerous and unpredictable context in which state institutions are embedded, they help to 'regularize' and increase the predictability of the situation for all concerned.

Supporting the practical norms which are in place to counter difficulties, unpredictability and uncertainties, personal relationships also play an important role (Odegaard 2008; Staudt 1998; Mahmoud 2008). Traders constantly try to personalize their various engagements with state agencies in order to reduce the unpredictability of the trade. It is clear that a trader who has a good relationship with a customs official or soldier will have less difficulty in dealing with them than an anonymous trader. The latter, however, can 'hire' certain actors to help him at the interface with government agencies. These actors act as informal intermediates/brokers to help the transaction to occur, again reducing the unpredictability of the trade. Blundo (2006) gives a detailed overview of how brokers help to initiate users into the administrative system. A similar observation can be made in the case of north-western Uganda. For example, certain Ugandan governmental officers act as informal brokers to under-declare goods: this is for example the case for the trade in timber, where customs brokers are 'hired' because they can guarantee the under-declaration of goods. The same thing happens across the border, where Sudanese security agencies or forestry officers are 'hired' to guarantee the under-declaration of timber, so that earlier under-declarations are not challenged. In other words, the actors who are supposed to implement the legal framework make sure traders are able to act outside of the legal framework and guarantee varying degrees of protection in this legal vacuum. Discussing the border points in eastern DRC, Tegera and Johnson call this interaction between traders and government officials 'fraud among consenting adults' as a 'convenient way for individuals on both sides to profit from non-legality' (2007: 34 ). This does not always require monetary compensation, but can also be arranged through 'friendships', in which non-monetary compensation is given to these protective actors. For example, local traders in Arua perceive it as legitimate to charge higher prices to Sudanese traders who come to buy goods in the town. There are, however, Ugandan traders who act as

\footnotetext{
${ }^{20}$ As opposed to 'processes of regularization', 'processes of situational adjustment' are those in which 'people arrange their immediate situations... by exploiting the indeterminacies in the situation, or by generating such indeterminacies ... . These strategies continuously reinject elements of indeterminacy into social negotiations, making active use of them and making absolute ordering the more impossible' (Moore 1978: 50).
} 
intermediaries in this case: they help Sudanese to buy goods and make sure they are treated correctly. They do not charge money for this, but the service is returned in a non-financial way-the same Sudanese (or their relations) in turn help the Ugandans to trade in southern Sudan. In other words, foreign traders operate in an unpredictable environment, but they can enhance its predictability by associating themselves with local traders. The point here is that protection or intermediation is needed not only to cross the divide between state and non-state actors, but also to negotiate other social divides.

Finally, personal relations are not only important in countering the unpredictability of the cross-border trade for traders (Odegaard 2008; Mahmoud 2008; Staudt 1998), but also for state agents: it has been demonstrated above that they also find themselves in a rather unpredictable and hostile environment, and are in constant negotiation with traders and the wider community. Personalizing the relationship between trader and government official creates advantages for both parties. In doing so, the government official may create better relationships with the community, protect himself against potential difficulties and inform himself about possible irregularities within this 'moral economy' of the cross-border trade. For example, field research in 2008 revealed the case of a trader whose activities had been reported by fellow traders to government officials. He was importing weapons from eastern Congo, which he then rented out and/or sold to thieves in the area - a practice that other traders considered illegitimate. This does not mean that the weapons trade is automatically considered immoral: a big Arua trader who was accused by the UN panel of supplying weapons to Congolese rebels was and is strongly defended by the local population (traders, politicians, religious organizations, and so on). The first trader was informed on because his practices brought damage to the area, while the second trader was protected because he was seen as a typical example of a successful businessman 'fending for himself' through cross-border trade. Even though it involved arms trading, it did not cause harm to the area (in Uganda, that is). On the contrary, the trader had provided many services to the community, such as constructing churches or roads.

\section{CONCLUSION}

Examining these practical norms has offered more insight into what Lund calls 'the processual aspects of the formation of public authority' (2006: 276). These norms are central in the regulation of cross-border trade, a field which does not escape regulation although it largely takes place outside of the legal framework. In considering practical norms we have shown that there is a divergence between official norms, social norms and actual behaviour. This is nothing new, but the article has analysed a variety of practices established in the field and the mechanisms through which they were maintained. Rather than simply being interpreted as governed by alternative systems of legitimacy, these practical norms should be seen as part of an ongoing negotiation, 
or what Peter Andreas (2000) calls 'border games': the interaction between government officials at the border and the unauthorized border crossers. As Abraham and van Schendel (2005: 25) emphasize, these border games are not only about strategic interactions between government officials and border crossers, but also about fundamentally different perceptions of licitness. 'Threshold days', in which customs points temporarily decide to lower their taxes, is a good example of the hybrid bricolage that ensues. Not only does this show how stateness 'waxes and wanes'; state institutions also resemble what Lund (2006) calls 'twilight institutions' that defy clear-cut state/society, public/private distinctions. Because of the difficult circumstances in which government officials have to function, they have come to rely on practical norms that are different from the national state regulations, and which integrate wider concerns from the community; something which is in turn influenced by the power position of the traders.

All this does not necessarily run against the interests of the national state. Government officials continue to act within the state framework and do not act against the state's interests: because practical norms help government institutions to function, the state is careful to conserve them. This situation is therefore in line with what Janet Roitman calls the 'contradictory' or 'ambiguous' relationship between the state and actors in the extra-state economy, between the 'formal' and 'informal', in which the state benefits from competing regimes of power (Roitman 2004: 168). In this case, the Ugandan state gains a clear political advantage from accommodating the extra-state economic activities in its margins. Although these extra-state cross-border activities deprive the state of resources, they 'return them to society in many ways' (Vwakyanakazi 1991: 69), as they constitute a local solution to a particular problem, in this case economic underdevelopment and political marginalization. In other words, all these practices, many of which are in theory illegal, do not automatically 'undermine the recursive patterns of rule at the heart of national political order and integration' (Chalfin 2001: 203). On the contrary, they are essential to the functioning of the latter.

\section{ACKNOWLEDGEMENTS}

The authors would like to thank Kate Meagher and Africa's two anonymous referees for their comments on an earlier draft of this article. Kristof Titeca's field research was financed through grants from the Crisis States Research Programme (London School of Economics), Institute of Development Policy and Management (University of Antwerp) and the Fund for Scientific Research - Flanders.

\section{REFERENCES}

Abraham, I. and W. van Schendel (2005) 'Introduction: the making of illicitness' in I. Abraham and W. van Schendel (eds), Illicit Flows and Criminal Things. Bloomington and Indianapolis IN: Indiana University Press. 
Andreas, P. (2000) Border Games: policing the US-Mexico divide. Ithaca NY: Cornell University Press.

Bayart, J.-F. (1999) 'The "social capital" of the felonious state' in J.-F. Bayart, S. Ellis and B. Hibou (eds), The Criminalization of the State in Africa. Oxford, Bloomington and Indianapolis IN: James Currey and Indiana University Press.

- (2004) 'Le crime national et la formation de l'état', Politique africaine 93: 93-104.

Blundo, G. (2006) 'Dealing with the local state: the informal privatization of street-level bureaucracies in Senegal', Development and Change 37 (4): 799-819.

Bromley, R. (1978) 'Organization, regulation and exploitation in the socalled "urban informal sector": the street traders of Cali, Colombia', World Development 6: 1161-71.

Chabal, P. and J.-P. Daloz (1999) Africa Works: the political instrumentalization of disorder. Oxford and Bloomington IN: International African Institute in association with James Currey and Indiana University Press.

Chalfin, B. (2001) 'Border zone trade and the economic boundaries of the state in north-east Ghana', Africa 71 (2): 202-24.

Cleaver, F. (2002) 'Reinventing institutions: bricolage and the social embeddedness of natural resource management', European fournal of Development Research 14 (2): 11-30.

Cross, J. (1998) Informal Politics: street vendors and the state in Mexico City. Stanford CA: Stanford University Press.

Das, V. and D. Poole (eds) (2004) Anthropology in the Margins of the State. Sante Fe and Oxford: School of American Research Press and James Currey.

de Certeau, M. (1984) The Practices of Everyday Life. Berkeley CA: University of California Press.

de Soto, H. (2000) The Mystery of Capital: why capitalism triumphs in the West and fails everywhere else. New York NY: Basic Books.

DfID (2007) 'The timber trade and poverty alleviation, Upper Great Lakes region'. Report prepared by Forests Monitor for the Department for International Development, $\langle\mathrm{http} / /$ webarchive.nationalarchives.gov.uk/+/ http ://www.dfid.gov.uk/Documents/publications/forests_monitor.pdf/, accessed 1 July 2010.

Gambetta, D. (1993) The Sicilian Mafia: the business of private protection. Cambridge MA: Harvard University Press.

Hagedorn, J. M. (1994) 'Neighborhoods, markets and gang drug organization', Fournal of Research in Crime and Delinquency 31 (3): 264-94.

Hart, K. (1995) 'L'entreprise africaine et l'économie informelle: réflexions autobiographiques' in S. Ellis and Y. A. Fauré (eds), Entreprises et entrepreneurs africains. Paris: Karthala/Orstrom. (2001) Money in an Unequal World. New York NY: Texere.

Hecht, D. and M. Simone (1994) Invisible Governance: the art of African micropolitics. New York NY: Autonomedia.

Hibou, B. (1999) 'The "social capital" of the state as an agent of deception' in J.-F. Bayart, S. Ellis and B. Hibou (eds), The Criminalization of the State in Africa. Oxford, Bloomington and Indianapolis IN: James Currey and Indiana University Press.

Kelsall, T. (2009) 'Game-theoretic models, social mechanisms and public goods in Africa: a methodological discussion', Discussion Paper No. 7, Africa Power and Politics Research Programme, December 2009. 
Klein, A. (1999) 'The barracuda's tale: trawlers, the informal sector and a state of classificatory disorder off the Nigerian coast', Africa 69 (4): 555-74.

Leopold, M. (2005) Inside West Nile. Oxford: James Currey.

Little, P. (2005) 'Unofficial trade when states are weak', Research Paper No. 2005/13, Expert Group on Development Issues (EGDI) and United Nations University-World Institute for Economic Development Research (UNUWIDER).

Lund, C. (1998) 'Struggles for land and political power: on the politicization of land tenure and disputes in Niger', Fournal of Legal Pluralism 40: 1-22.

- (2006) 'Twilight institutions: public authority and local politics in Africa', Development and Change 37 (4): 685-705.

MacGaffey, J. (1987) Entrepreneurs and Parasites: the struggle for indigenous capitalism in Zaire. Cambridge: Cambridge University Press. (ed.) (1991) The Real Economy of Zaire. London and Philadelphia PA: James Currey and University of Pennsylvania Press.

MacGaffey, J. and R. Bazenguissa-Ganga (2000) Congo-Paris: transnational traders on the margins of the law. Oxford, Bloomington and Indianapolis IN: International African Institute in association with James Currey and Indiana University Press.

Mahmoud, H. S. (2008) 'Risky trade, resilient traders: trust and livestock marketing in northern Kenya', Africa 78 (4): 561-81.

Meagher, K. (1990) 'The hidden economy: informal and parallel trade in northwestern Uganda', Review of African Political Economy 47: 64-83.

- (2008) 'Informality matters: popular economic governance and institutional exclusion in Nigeria', unpublished paper presented at St Antony's College, Oxford, 11-12 January 2008.

Migdal, J. S. (1994) 'The state in society: an approach to struggles for domination' in J. S. Migdal, A. Kohli and V. Shue (eds), State Power and Social Forces: domination and transformation in the Third World. Cambridge: Cambridge University Press.

Migdal, J. S. and K. Schlichte (2005) 'Re-thinking the state' in K. Schlichte (ed.), The Dynamics of States: the formation and crises of state domination. Burlington VT: Ashgate.

Moore, S. F. (1978) Law as Process. London: Routledge and Kegan Paul.

Mwenda, A. (2008) 'National cake: who eats the chunk, who picks crumbs?' The Independent (Uganda), 8-21 February.

Nalugo, M. (2008) 'Banyankole, Baganda lead URA employees list-report', Daily Monitor, 30 January.

Nordstrom, C. (2004) Shadows of War: violence, power, and international profiteering in the twenty-first century. Berkeley, Los Angeles CA and London: University of California Press.

Nugent, P. and A. I. Asiwaju (1996) African Boundaries: barriers, conduits and opportunities. London and New York NY: Pinter.

Odegaard, C. V. (2008) 'Informal trade, Contrabando and prosperous socialities in Arequipa, Peru' Ethnos 73 (2): 241-66.

Olivier de Sardan, J.-P. (2005) Anthropology and Development: understanding contemporary social change. London and New York NY: Zed Books.

(2009) 'Researching the practical norms of real governance in Africa', Discussion Paper No. 5, Africa Power and Politics Research Programme, December 2009.

Pugh, M. and N. Cooper (2004) War Economies in a Regional Context: challenges of transformation. Boulder CO and London: Lynne Rienner. 
Reno, W. (1998) Warlord Politics and African States. Boulder CO and London: Lynne Rienner.

(2000) 'Clandestine economies, violence and states in Africa', fournal of International Affairs 53 (2): 433-59.

Reuter, P. (1985) The Organization of Illegal Markets. Port Townsend WA: Loompanics Limited.

Ribot, J. C. (1998) 'Theorizing access: forest profits along Senegal's charcoal commodity chain', Development and Change 29 (2): 307-41.

Rodgers, D. (2006) 'Living in the shadow of death: gangs, violence and social order in Nicaragua, 1996-2002', Fournal of Latin American Studies 38 (2): 267-92.

Roitman, J. (2004) Fiscal Disobedience: an anthropology of economic regulation in Central Africa. Princeton NJ and Oxford: Princeton University Press.

Schomerus, M. (2008) 'Perilous border: Sudanese communities affected by conflict on the Sudan-Uganda border', study for Conciliation Resources, London, November.

Scott, J. C. (1976) The Moral Economy of the Peasant: rebellion and subsistence in Southeast Asia. New Haven CT and London: Yale University Press.

Staudt, K. (1998) Free Trade? Informal economies at the US-Mexico border. Philadelphia PA: Temple University Press.

Steinmetz, G. (1999) 'Introduction: culture and the state' in G. Steinmetz (ed.), State/Culture: state formation after the cultural turn. Durham NC: Duke University Press.

Tegera, A. and D. Johnson (2007) 'Rules for sale: formal and informal crossborder trade in DRC' (a Pole Institute Report), Regards Croises (Revue Trimestrielle) 19 (May).

Titeca, K. (2006) 'Les Opec Boys en Ouganda, trafiquants de pétrole et acteurs politiques', Politique africaine 103: 143-59.

- (2009a) "The "Masai" and "miraa": public authority, vigilance and criminality in a Ugandan border town', Fournal of Modern African Studies 47 (2): 291-317.

- (2009b) 'The changing cross-border trade dynamics between northwestern Uganda, north-eastern Congo and southern Sudan', Working Paper No. 63, Crisis States Research Centre, November.

Titeca, K. and T. Vervisch (2008) 'The dynamics of social capital and community associations in Uganda: linking capital and its consequences', World Development 36 (11): 2205-22.

Uganda Bureau of Statistics (UBOS) (2007) The Informal Cross Border Trade Survey Report 2006. Kampala: UBOS and Bank of Uganda.

- (2008) The Informal Cross Border Trade Survey Report 2007. Kampala: UBOS and Bank of Uganda.

Varese, F. (2001) The Russian Mafia: private protection in a new market economy. Oxford: Oxford University Press.

Venkatesh, S. and S. Levitt (2000) “ "Are we a family or a business?” History and disjuncture in the urban American street gang', Theory and Society 29: 427-46.

Vwakyanakazi, M. (1991) 'Import and export in the second economy in North Kivu' in J. MacGaffey (ed.), The Real Economy of Zaire. London and Philadelphia PA: James Currey and University of Pennsylvania Press. 


\section{ABSTRACT}

This article describes how cross-border trade in West Nile, north-western Uganda to a large extent takes place outside of the legal framework. This does not mean that this trade is unregulated. We make use of the concept of 'practical norms' to show the existence of regulation within this trade, which diverges both from official norms and social norms ('moral economy'). The article describes how these practical norms emerged and how they are enforced. First, it is shown how the moral economy of cross-border trade plays an important role in their articulation. Second, we ask which practical concerns play a role in sustaining these norms and how deviations from them activate open power struggles. And third, we show how concrete events have played a role in their emergence.

\section{RÉSUMÉ}

Cet article décrit la manière dont le commerce transfrontalier se déroule dans une large mesure en dehors du cadre juridique dans la région du Nil occidental située au Nord-Ouest de l'Ouganda. Ceci ne veut pas dire que ce commerce n'est pas réglementé. L'article utilise le concept de "normes pratiques " pour montrer l'existence d'une réglementation, au sein de ce commerce, qui diverge à la fois des normes officielles et des normes sociales (" économie morale "). Il décrit l'émergence de ces normes pratiques et leur mise en œuvre. Tout d'abord, il montre le rôle important que joue l'économie morale du commerce transfrontalier dans leur articulation. Ensuite, il étudie les préoccupations pratiques qui jouent un rôle dans le maintien de ces normes et les luttes de pouvoir ouvertes que déclenche le non-respect de ces normes. Enfin, il montre le rôle qu'ont joué des événements concrets dans leur émergence. 
Copyright of Africa is the property of Edinburgh University Press and its content may not be copied or emailed to multiple sites or posted to a listserv without the copyright holder's express written permission. However, users may print, download, or email articles for individual use. 